\title{
Un-rooted grafted cuttings for eggplant plug-transplant production and shipping: simulated transportation and
}

\section{healing requirements}

\author{
L. Sabatino, F. D'Anna and G. Iapichino \\ Department of Agricultural, Alimentary and Forest Sciences, University of Palermo, Palermo, Italy
}

\begin{abstract}
Summary
Vegetable grafting is one of the most effective eco-friendly techniques to overcome pests and soilborne diseases in modern cropping systems of fruiting vegetables. Due to the increased farmers' preference for grafted seedlings of high quality and better performance, the use of vegetable grafted plants is rapidly spreading and expanding over the world and intensive researches on new commercial production systems are under way. However, in many areas of the world, due to the high cost of skilled manpower, the use of grafted plug plants is still limited causing a relatively slow development of the grafting nursery industry. The aim of this work was to evaluate a possible use of un-rooted grafted cuttings as means of propagation and distribution of eggplant transplants. In this experiment, un-rooted grafted eggplant cuttings ('Birgah' eggplant scion with Solanum torvum rootstock) harvested after diverse healing times [0 (DIH 0), 1 (DIH 1), 3 (DIH 3), 5 (DIH 5), or 7 (DIH 7) days in healing] were exposed to 20,14 and $8^{\circ} \mathrm{C}$ 'simulated transportation temperature' and dark condition in a growth chamber for 72 hours. After 72 hours of the simulated transportation treatment, all un-rooted grafted cuttings were transferred into the greenhouse for rooting. The results showed that $S$. torvum is a suitable rootstock for applying the un-rooted grafted cutting propagation technique. All grafted cuttings reached the grafting success $(100 \%)$ and all un-rooted grafted cuttings developed roots at the end of the rooting stage $(100 \%)$. Regardless of the simulated shipping conditions, the treatment DIH 0 gave the best results in terms of number of leaves after rooting (3.8 leaves), shoot fresh and dry weight after 7 days of growth (3.92 and $0.46 \mathrm{~g}$, respectively), fresh weight of the roots (1.34 g), and plantlet visual quality of the finished plug transplants (8.8). This innovative production/shipping method might be successfully used in areas where local nurseries do not have high grafting ability.
\end{abstract}

\section{Keywords}

propagation technique, plantlet transportation method, graft-healing time, Solanum melongena, Solanum torvum, controlled environment

\section{Introduction}

Eggplant (Solanum melongena L.) is a member of the Solanaceous family and produces fruits widely consumed

\section{Significance of this study}

What is already known on this subject?

- Grafting of eggplant onto Solanum torvum Sw. rootstock is considered a feasible alternative for the control of biotic and/or abiotic stresses of Solanum melongena grafted cultivars. However, the long, irregular and erratic seed germination of S. torvum has been a limiting factor in commercial nursery development. Although some authors have proposed the use of un-rooted grafted cuttings for eggplant, the application of this propagation technique for eggplant plug-transplant production and shipping has not been examined yet.

What are the new findings?

- Shipping un-rooted grafted eggplant cuttings ('Birgah' eggplant scion with Solanum torvum rootstock) immediately after grafting results in optimal posttransportation growth, satisfactory development, high plantlet visual quality and therefore in an improved plant nursery efficiency. Shipping and rooting conditions adopted in this study were suitable for optimal graft-healing.

What is the expected impact on horticulture?

- This innovative shipping method might improve the use/cultivation of eggplant grafted plantlets, especially in those areas where, due to the high cost of skilled manpower, local nurseries do not have high grafting ability.

in various parts of the world. It is extensively cultivated in tropical and temperate regions around the world and is amenable to grafting (Bletsos et al., 2003). Eggplant global production is estimated to be around $49.5 \mathrm{Mt}$ and is mainly concentrated in Asia (93\% of both the world production and harvested area), with China, India, Indonesia and Iran, representing the major producers. Egypt, Turkey, and Italy are the main producers of the Mediterranean countries (FAO, 2016; http://faostat3.fao.org/browse/Q/QC/E). Recent policy environmental regulations have led to an increase of commercial supply and use of grafted vegetable seedlings throughout the world. Vegetable grafting is not only considered a feasible alternative for controlling soil-borne pathogens, but also for inducing resistance against low and high temperatures (Rivero et al., 2003; Venema et al., 2008), improving yield and product quality, enhancing capability of absorbing water and nutrients more efficiently than scion roots (Col- 
la et al., 2010; Rouphael et al., 2008), supplying endogenous plant hormones (Dong et al., 2008), reducing uptake of persistent, organic pollutants from agricultural soils (Otani and Seike, 2006, 2007), improving alkalinity tolerance (Colla et al., 2010b), raising salt and flooding tolerance (Martinez-Rodriguez et al., 2008; He et al., 2009), and limiting the negative effect of metal toxicity (Rouphael et al., 2008b; Savvas et al., 2009).

Eggplant significantly benefits from grafting because soil-borne pathogens and other abiotic stresses can cause important production losses (Bletsos et al., 2003). The wild relative Solanum torvum Sw., which has resistance to a wide range of soil-borne pathogens such as bacterial wilt, Fusarium wilt, Verticillium wilt, root-knot nematode (King et al., 2010; Gisbert et al., 2011; Bagnaresi et al., 2013) and induces high vigor to the scion (Sabatino et al., 2013, 2018), is recommended for eggplant grafting (Bletsos et al., 2003; King et al., 2010; Sabatino et al., 2016).

Even though large-scale commercial production of vegetable seedlings is expanding rapidly in many developed and less-developed countries, there are many problems associated with cultivating grafted vegetable seedlings. Major problems are the large labor and high skilled technique required for the grafting operation and post-graft handling of grafted seedlings for rapid healing ( 7 to 10 days), and high transportation costs associated to long distance delivery of grafted seedlings. A feasible solution to reduce cost might be a model similar to that applied in the floricultural industry in which an offshore company ships un-rooted cuttings to another company for rooting. In the technique proposed by Shibuya et al. (2007), grafted cuttings, obtained by grafting cucumber scions on squash rootstock cuttings harvested from seedlings, are prepared in the primary nursery and shipped to a secondary nursery where they are planted in a growing medium for rooting. Cutting survival through the long distance transportation and adequate secondary nursery facilities for healing the grafted cuttings are main prerequisites for this technique to be successful.

Some authors suggested the use of un-rooted grafted cuttings for tomato, cucumber (Shiraki et al., 1999), and eggplant (Miceli et al., 2014). However, the application of this propagation technique on eggplant plantlets shipping has not been examined yet. This propagation/transportation technique might have an effect on grafting success and after-transportation seedling development. Furthermore, there could be an optimal healing duration time inferior to the standard period (7 days) that allows the un-rooted grafted cuttings to survive after shipping. The aim of this research was to evaluate a possible use of un-rooted grafted cuttings as means of propagation and distribution of eggplant transplants under simulated transportation temperature to find their healing requirements.

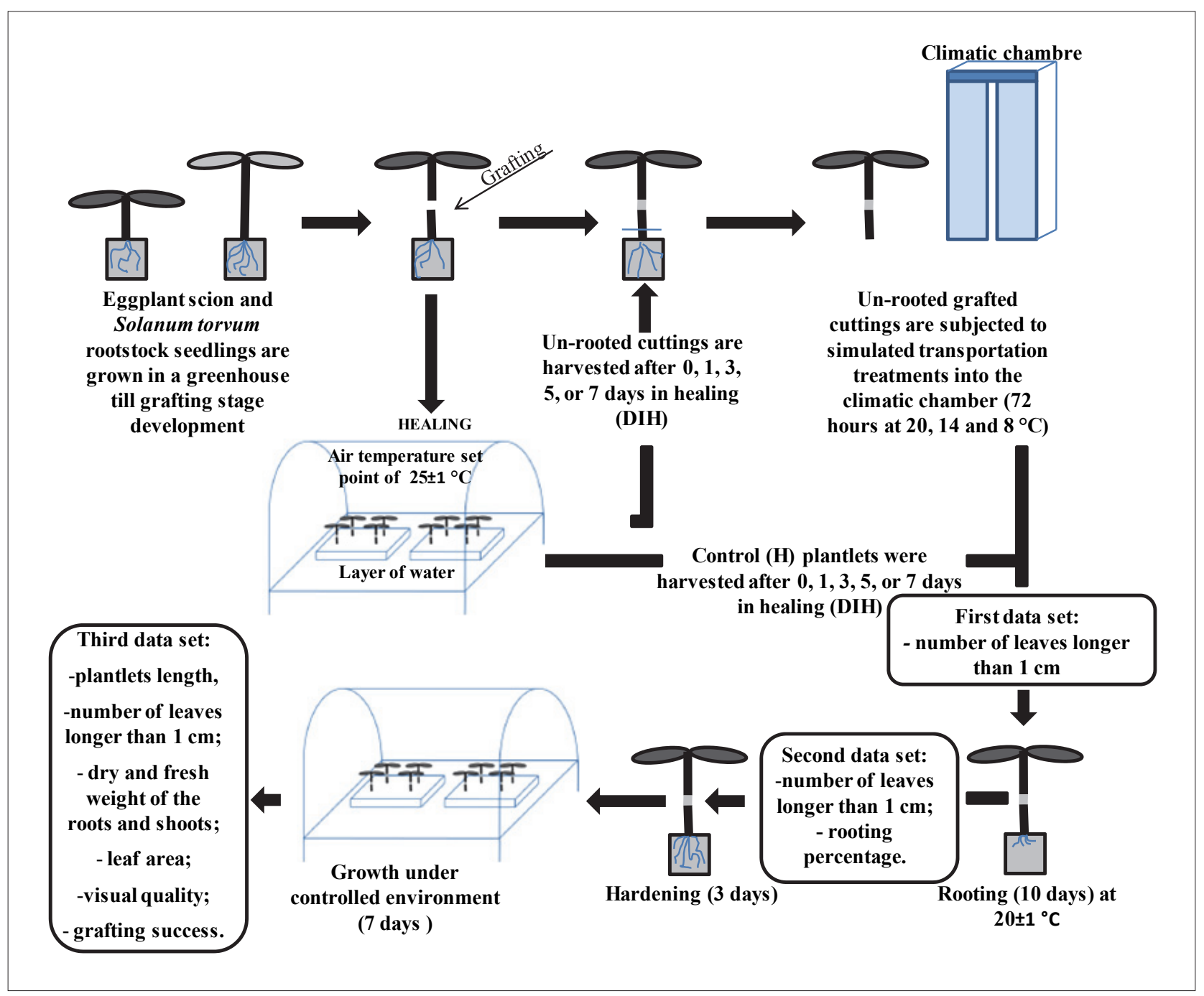

FIGURE 1. Diagram of the grafting procedure and simulated shipping treatments of eggplant un-rooted grafted cuttings. 


\section{Materials and methods}

\section{Plant materials and grafted seedlings production}

The trial was conducted in 2015 at the experimental farm of the Department of Agricultural, Alimentary and Forest Sciences, University of Palermo, Italy $\left(38^{\circ} 9^{\prime} 23^{\prime \prime} \mathrm{N}, 13^{\circ} 20^{\prime} 2^{\prime \prime} \mathrm{E}\right.$; altitude $48 \mathrm{~m}$ ). A $9 \times 25 \mathrm{~m}$ controlled-temperature greenhouse was used for the experiment. The greenhouse was equipped with mobile benches, high pressure fogging and overhead air heating systems.

'Birgah' eggplant was used as scion variety (Monsanto, St. Louis, MO) and S. torvum as rootstock (Fenix Seed, Catania, Italia). Scion and rootstock were sown into 66 cell polystyrene trays (cell volume of $55 \mathrm{~mL}$ ) containing a 80:20 (v/v) substrate mix of peat moss (FAP, Padova, Italia) and coconut fiber (Polyplants, Lucca, Italia). After sowing all trays were moved in a temperature controlled greenhouse. The temperature was set at $25 \pm 1^{\circ} \mathrm{C}$ till the seed germination. After germination, air temperature was set at $25 \pm 1 / 18 \pm 1^{\circ} \mathrm{C}$ (day/ night). 'Birgah' seeds were sown 25 days after $S$. torvum seeds, so that all seedlings could reach the growth stage suitable for grafting at the same time. Grafting was performed using the tube grafting method as described by Lee et al. (2010), but using grafting plastic clips rather than silicon tubes. The grafted plantlets were immediately misted and maintained into a humidity chamber made with a plastic tunnel inside the temperature controlled greenhouse maintaining darkness for 24 hours at a temperature set point of $25 \pm 1^{\circ} \mathrm{C}$ and a humidity rate of $95-100 \%$ to encourage healing processes. Subsequently, the level of the light was increased to at 55 mol m${ }^{-2} \mathrm{~s}^{-1}$ photosynthetic photon flux density (PPFD) (additional light plus natural light) using T5 white fluorescent tubes (Philips TL-D 36W 840). After 5 days from grafting, the humidity chamber was opened slightly for acclimatizing the seedlings under lower humidity.

\section{Simulated shipping treatments and rooting conditions}

Grafted plantlets were harvested at root collar level (just above the area where the roots join the stem), so that uniform grafted cuttings were obtained. Grafted cuttings were harvested after diverse days in healing (DIH) [0 (DIH 0), 1 (DIH 1), 3 (DIH 3), 5 (DIH 5), or 7 (DIH 7) days after grafting] and thereafter placed into a 7-layer polyethylene plastic bag [18 $\times 28 \mathrm{~cm}$ (total volume of $1.5 \mathrm{~L}$ )] (5 grafted cuttings per plastic bag) for maintaining moisture. The plastic bags were placed, horizontally oriented, into a climatic chamber in dark condition at 20,14 and $8^{\circ} \mathrm{C}$ for 72 hours. The shipping duration (72 hours) was chosen based on the air travel expected duration associating handlings of cuttings in Europe. Control groups included un-rooted grafted cuttings harvested after $0,1,3,5$, and 7 days from grafting and placed in rooting conditions without applying the shipping treatment (non-treated control) (Figure 1). The timeline of the fifteen shipping treatments and that of the five control group are reported in Table 1.

After the shipping treatment, all the shipped un-rooted grafted cuttings, included the non-treated control, were subjected to rooting without plant growth regulators. The un-rooted grafted cuttings were plugged in a 66 cell polystyrene tray filled with a 80:20 (v/v) substrate mix of peat moss (FAP, Padova, Italia) and coconut fiber (Polyplants, Lucca, Italia) and placed into a shaded humidity chamber (plastic tunnel with $80 \%$ of shade located in the greenhouse) with a layer of water for humidity (about 98\% RH). Air temperature

TABLE 1. Timeline of simulated shipping conditions and non-shipping controls of unrooted grafted cutting of eggplant plantlets.

\begin{tabular}{|c|c|c|c|c|c|}
\hline Treatments & $\begin{array}{l}\text { Days in healing } \\
\text { (days) }\end{array}$ & $\begin{array}{l}\text { Shipping simulated } \\
\text { conditions }\end{array}$ & $\begin{array}{l}\text { Shipping time } \\
\text { (days) }\end{array}$ & $\begin{array}{l}\text { Days of rooting } \\
\text { (days) }\end{array}$ & $\begin{array}{c}\text { Days in healing } \\
\text { treatment and rooting } \\
\text { (days) }\end{array}$ \\
\hline DIH O (control H) & 0 & No shipping & NA & 10 & 10 \\
\hline DIH 0 & 0 & $20^{\circ} \mathrm{C}$ & 3 & 10 & 13 \\
\hline $\mathrm{DIH} 0$ & 0 & $14^{\circ} \mathrm{C}$ & 3 & 10 & 13 \\
\hline DIH 0 & 0 & $8^{\circ} \mathrm{C}$ & 3 & 10 & 13 \\
\hline DIH 1 (control H) & 1 & No shipping & NA & 10 & 11 \\
\hline DIH 1 & 1 & $20^{\circ} \mathrm{C}$ & 3 & 10 & 14 \\
\hline DIH 1 & 1 & $14^{\circ} \mathrm{C}$ & 3 & 10 & 14 \\
\hline DIH 1 & 1 & $8^{\circ} \mathrm{C}$ & 3 & 10 & 14 \\
\hline DIH 3 (control H) & 3 & No shipping & NA & 10 & 13 \\
\hline DIH 3 & 3 & $20^{\circ} \mathrm{C}$ & 3 & 10 & 16 \\
\hline $\mathrm{DIH} 3$ & 3 & $14^{\circ} \mathrm{C}$ & 3 & 10 & 16 \\
\hline DIH 3 & 3 & $8^{\circ} \mathrm{C}$ & 3 & 10 & 16 \\
\hline DIH 5 (control H) & 5 & No shipping & NA & 10 & 15 \\
\hline DIH 5 & 5 & $20^{\circ} \mathrm{C}$ & 3 & 10 & 18 \\
\hline DIH 5 & 5 & $14^{\circ} \mathrm{C}$ & 3 & 10 & 18 \\
\hline DIH 5 & 5 & $8^{\circ} \mathrm{C}$ & 3 & 10 & 18 \\
\hline DIH 7 (control H) & 7 & No shipping & NA & 10 & 17 \\
\hline DIH 7 & 7 & $20^{\circ} \mathrm{C}$ & 3 & 10 & 20 \\
\hline $\mathrm{DIH} 7$ & 7 & $14^{\circ} \mathrm{C}$ & 3 & 10 & 20 \\
\hline $\mathrm{DIH} 7$ & 7 & $8^{\circ} \mathrm{C}$ & 3 & 10 & 20 \\
\hline
\end{tabular}

NA: not applicable.

Control $(H)=$ no shipping. 
in the shaded humidity chamber was $20 \pm 1^{\circ} \mathrm{C}$ constant.

Plastic supports were used to maintain trays elevated above the water level. On the $9^{\text {th }}$ day, the humidity chamber was open to permit a slow humidity dropping. After 24 hours the rooted plants were transferred to the bench with $50 \%$ shade (into a greenhouse) for one day. Subsequently, the plantlets were placed under the full sun (unshaded greenhouse), for additional 3 days, in order to complete the hardening.

\section{Growth, development rates and plantlet visual quality evaluation}

In order to assess quality of grafted plantlets, the measurements were recorded four times. The first data set was taken at planting ( 72 hours), for the number of leaves longer than $1 \mathrm{~cm}$. The second data set was performed after root emergence, and the data of the number of leaves longer than $1 \mathrm{~cm}$ and the rooting percentage were recorded. The third data set was taken after 7 days from when plants have completed the hardening phase. Plantlets length, number of leaves longer than $1 \mathrm{~cm}$, dry and fresh weight of the roots and shoots, leaf area and grafting success were recorded. The dry matter was obtained by drying samples in a thermo-ventilated oven (M40-VF, Artiglass, Padova, Italia) at $80^{\circ} \mathrm{C}$ for 3 days till constant weight was reached. Visual quality of the rooted grafted cuttings, after 7 days of growth, was scored on a 9 to 1 continuous scale, where 9 refers to excellent appearance, 7 to good, 5 to fair (limit of marketability), 3 to fair (useable but not saleable), 1 to unusable.

\section{Experimental design and statistical analysis}

Treatments were defined by a completely randomized design with five replicates per treatment, each consisting of 25 un-rooted grafted cuttings. A two-way ANOVA [days in healing $(\mathrm{DIH}) \times$ shipping simulated conditions (SSC)] was used to determine the effects of different simulated shipping treatments. Mean separation was performed by Duncan's multiple-range test. Percentages were subjected to angular transformation prior to perform statistical analysis $(\Phi=$ arc- $\left.\sin (\mathrm{p} / 100)^{1 / 2}\right)$. Data obtained were statistically analyzed using SPSS software version 14.0 (StatSoft, Inc., Chicago, USA).

\section{Results}

\section{Shipping and rooting of un-rooted grafted cuttings of eggplant}

All grafted cuttings (Table 1) achieved the grafting success $(100 \%)$, consequently, no differences neither due to days in healing nor due to shipping simulated conditions were observed (Table 3). All un-rooted grafted cuttings developed roots at the end of the rooting stage (100\%) (Table 2). Thus, all plantlets were suitable for recording data.

Days in healing and SSC affected plantlets growth from grafting to the end of the nursery trial (Tables 2-4). Regardless of SSC no significantly differences were found in terms of number of leaves at planting (Table 2). Irrespective of the days in healing, the plantlets subjected to the 20 and $14^{\circ} \mathrm{C}$ SSC showed a significantly higher number of leaves at planting (4.1 and 4.0 leaves, respectively) than plantlets subjected to the $8^{\circ} \mathrm{C} \mathrm{SSC}$ and to control $(\mathrm{H})$ plantlets. ANOVA for number of leaves at planting did not show a significant interaction $(\mathrm{DIH} \times \mathrm{T})($ Table 2$)$. Without regard of the SSC, the plantlets subjected to the DIH 0 treatment exhibited the highest number of leaves (3.8 leaves) after rooting, whereas the lowest value was found in plantlets from the DIH 7 treatment (3.1 leaves). Nevertheless, there were no significant differences in terms of number of leaves after rooting among DIH 0, DIH 1, and the DIH 3 treatments (Table 2). No significant interaction was found between days in healing and SSC.

\section{Re-growth of grafted cutting eggplant plantlets}

Data for re-growth of grafted cutting eggplant plantlets are presented in Table 3. Regardless of the SSC, the highest plantlet length was identified in plantlets from the DIH 3, DIH 5 and DIH 7 treatments, whereas, the lowest value was recorded in plantlets from DIH 0 treatment. Irrespective of the days in healing, the highest value in terms of plantlet length was recorded from plants subjected to the 20 and

TABLE 2. Effect of days in healing and simulated shipping at different temperatures on number of leaves at planting, number of leaves after rooting and rooting percentage.

\begin{tabular}{|c|c|c|c|}
\hline & $\begin{array}{l}\text { No. leaves at planting } \\
\text { (No.) }\end{array}$ & $\begin{array}{l}\text { No. leaves after rooting } \\
\text { (No.) }\end{array}$ & $\begin{array}{c}\text { Rooting percentage } \\
(\%)\end{array}$ \\
\hline \multicolumn{4}{|l|}{ Days in healing } \\
\hline 0 & 4.0NS & $3.8 \mathrm{a}$ & 100.0NS \\
\hline 1 & 3.8 & $3.4 a b c$ & 100.0 \\
\hline 3 & 3.8 & $3.6 a b$ & 100.0 \\
\hline 5 & 3.7 & $3.2 \mathrm{bc}$ & 100.0 \\
\hline 7 & 3.6 & $3.1 \mathrm{c}$ & 100.0 \\
\hline \multicolumn{4}{|l|}{ Shipping simulated conditions $\left({ }^{\circ} \mathrm{C}\right)$} \\
\hline No shipping = Control $(\mathrm{H})$ & $3.3 b$ & $3.5 a b$ & 100.0NS \\
\hline 20 & $4.4 a$ & $3.1 \mathrm{bc}$ & 100.0 \\
\hline 14 & $4.2 a$ & $3.9 a$ & 100.0 \\
\hline 8 & $3.2 b$ & $3.0 \mathrm{c}$ & 100.0 \\
\hline \multicolumn{4}{|l|}{ Significance } \\
\hline Days in healing (DIH) & NS & * & NS \\
\hline Shipping simulated conditions (SSC) & $* * *$ & $* * *$ & NS \\
\hline $\mathrm{DIH} \times \mathrm{SSC}$ & NS & NS & NS \\
\hline
\end{tabular}

Data within a column followed by the same letter are not significantly different at $p \leq 0.05$ according to Duncan's test. The significance is designated by asterisks as follows: *, statistically significant differences at $p$-value below $0.05 ;{ }^{* *}$, statistically significant differences at $p$-value below 0.01 ; ${ }^{* * *}$, statistically significant differences at $p$-value below $0.001 ; \mathrm{NS}=$ not significant. 


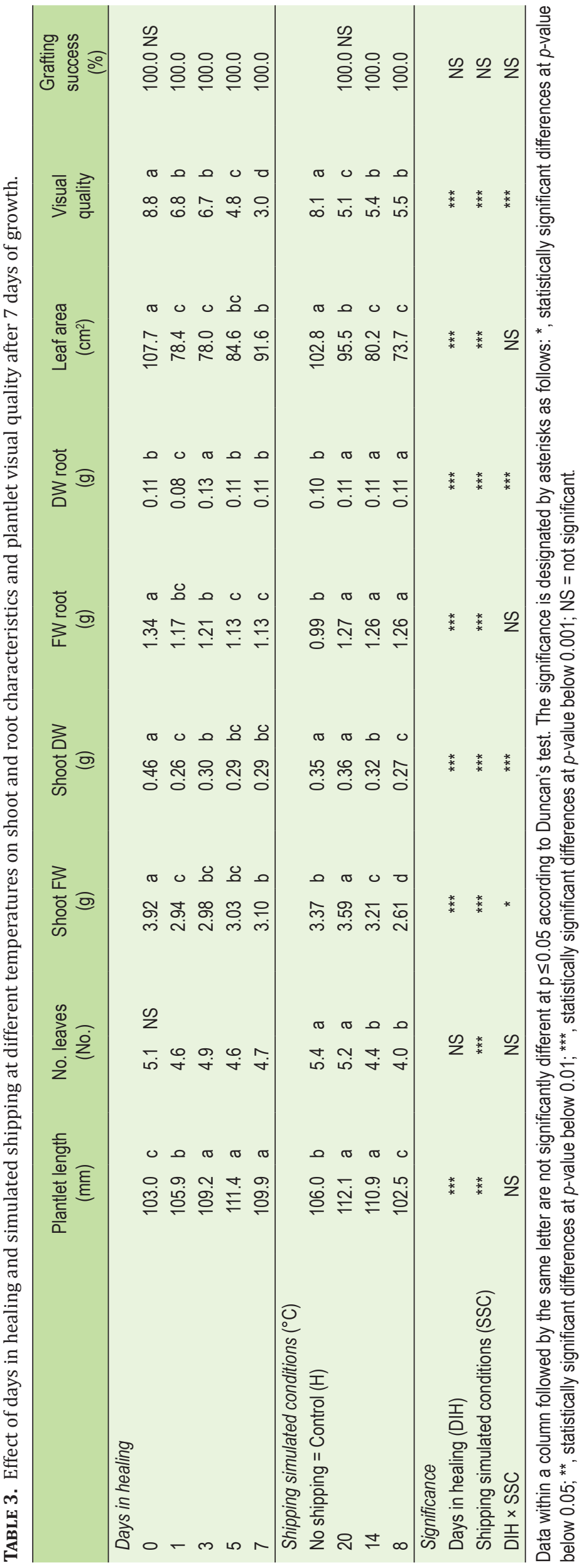

$14^{\circ} \mathrm{C}$ SSC (112.1 and $110.9 \mathrm{~mm}$, respectively). ANOVA for plantlet length did not show a significant interaction $(\mathrm{DIH} \times \mathrm{T})$. Irrespective of the SSC, days in healing did not significantly affect number of leaves after 7 days of growth. Conversely, SSC significantly affected the above mentioned plant parameter. The highest number of leaves after 7 days of growth was obtained from plantlets subjected to the $20^{\circ} \mathrm{C} \mathrm{SSC}$ and control (H) plantlets, which in turn were higher than those subjected to the 14 and $8^{\circ} \mathrm{C}$ SSC. ANOVA for number of leaves after 7 days of growth did not display a significant effect of the interaction DIH $\times$ SSC. Regardless of the SSC, plantlets from the DIH 0 treatment showed a significantly higher fresh weight of the shoots than those from DIH 7. The lowest shoot FW value was recorded in DIH 1 treatment. Irrespective of the days in healing, the highest shoot FW value was obtained from plantlets subjected to the $20^{\circ} \mathrm{C} \mathrm{SSC}$, which in turn was higher than control $(\mathrm{H})$ plantlets. The lowest value in terms of shoot FW was recorded from plantlets subjected to the $8^{\circ} \mathrm{C}$ SSC. ANOVA showed a significant interaction DIH $\times$ SST. The highest shoot FW was revealed from plantlets subjected to DIH $0 \times 20^{\circ} \mathrm{C}$ followed by DIH $0 \times 14^{\circ} \mathrm{C}$, whereas the lowest shoot FW was recorded from DIH $1 \times 8^{\circ} \mathrm{C}$, DIH $3 \times$ $8^{\circ} \mathrm{C}$, DIH $5 \times 8^{\circ} \mathrm{C}$ and DIH $7 \times 8^{\circ} \mathrm{C}$ (Table 4). Data collected on DW of the shoots supported the trend established for FW of the shoots (Tables 3 and 4). Disregarding of the SSC, grafted eggplant plantlets subjected to the DIH 0 treatment had the highest root FW value, followed by those from the DIH 3 treatment. Whereas, the lowest root FW values were recorded from plantlets subjected to the DIH 5 and DIH 7 treatments. Irrespective of the days in healing the highest root FW values were observed in plantlets exposed to a SSC of 20,14 , and $8^{\circ} \mathrm{C}$. ANOVA for root fresh weight did not reveal a significant effect of the interaction $\mathrm{DIH} \times \mathrm{SSC}$. As regard to root DW, irrespective of the SSC, DIH 3 plants exhibited the highest values followed by DIH 0, DIH 5, and DIH 7. The lowest root DW value was recorded in plants from DIH 1 treatment. Without regard of the days in healing, SSC significantly affected root DW. Plantlets exposed to SSC of 20,14 , and $8^{\circ} \mathrm{C}$ showed the highest root FW. ANOVA revealed a significant effect of the interaction DIH $\times$ SSC. The highest values in terms of root DW were collected from DIH $3 \times$ $20^{\circ} \mathrm{C}$, DIH $3 \times 14^{\circ} \mathrm{C}$, DIH $3 \times 8^{\circ} \mathrm{C}$., whereas the lowest ones were recorded from DIH 1 plantlets (Table 4).

Disregarding of the SSC, DIH 0 treatment showed the highest leaf area, followed by those from the DIH 7 treatment, whereas the lowest leaf area values were found in DIH 1 and DIH 3 plants. Irrespective of the days in healing, the highest leaf area value was obtained from plantlets subjected to the control $(\mathrm{H})$ plantlets, which in turn was higher than those subjected to the $20^{\circ} \mathrm{C}$ SSC. The lowest leaf area values were recorded from plantlets subjected to the 14 and $8^{\circ} \mathrm{C}$ SSC. ANOVA for leaf area did not display a significant effect of the interaction DIH $\times$ SSC. Regardless of the SSC, 
TABLE 4. Interactive effects of days in healing and simulate shipping at different temperatures on shoot FW, shoot DW, root DW and visual quality after 7 days of growth.

\begin{tabular}{|c|c|c|c|c|c|c|c|c|}
\hline \multirow[b]{2}{*}{ DIH $0 \times$ Control $(\mathrm{H})$} & \multicolumn{2}{|c|}{ Shoot FW (g) } & \multicolumn{2}{|c|}{ Shoot DW (g) } & \multicolumn{2}{|c|}{ DW root $(\mathrm{g})$} & \multicolumn{2}{|c|}{ Visual quality } \\
\hline & 3.78 & $\mathrm{c}$ & 0.41 & c & 0.10 & $\mathrm{~b}$ & 8.9 & $a$ \\
\hline $\mathrm{DIH} 0 \times 20^{\circ} \mathrm{C}$ & 4.43 & a & 0.53 & a & 0.11 & $b$ & 8.7 & a \\
\hline $\mathrm{DIH} 0 \times 14^{\circ} \mathrm{C}$ & 4.03 & $b$ & 0.49 & $b$ & 0.11 & $b$ & 8.8 & a \\
\hline $\mathrm{DIH} 0 \times 8^{\circ} \mathrm{C}$ & 3.43 & d & 0.42 & $c$ & 0.11 & $b$ & 8.9 & a \\
\hline DIH 1 × Control $(\mathrm{H})$ & 3.27 & de & 0.33 & $d$ & 0.08 & c & 8.3 & $b$ \\
\hline $\mathrm{DIH} 1 \times 20^{\circ} \mathrm{C}$ & 3.24 & e & 0.30 & e & 0.08 & c & 6.1 & e \\
\hline $\mathrm{DIH} 1 \times 14^{\circ} \mathrm{C}$ & 2.93 & $f$ & 0.27 & $f$ & 0.08 & c & 6.3 & e \\
\hline $\mathrm{DIH} 1 \times 8^{\circ} \mathrm{C}$ & 2.34 & g & 0.22 & $g$ & 0.08 & c & 6.4 & e \\
\hline DIH $3 \times$ Control $(\mathrm{H})$ & 3.26 & de & 0.33 & $d$ & 0.12 & $a b$ & 8.1 & $b$ \\
\hline $\mathrm{DIH} 3 \times 20^{\circ} \mathrm{C}$ & 3.33 & de & 0.33 & $d$ & 0.13 & a & 6.0 & $f$ \\
\hline $\mathrm{DIH} 3 \times 14^{\circ} \mathrm{C}$ & 2.98 & ef & 0.30 & e & 0.13 & a & 6.2 & e \\
\hline $\mathrm{DIH} 3 \times 8^{\circ} \mathrm{C}$ & 2.38 & $g$ & 0.24 & $g$ & 0.13 & a & 6.3 & e \\
\hline DIH $5 \times$ Control $(\mathrm{H})$ & 3.27 & de & 0.33 & $d$ & 0.10 & $b$ & 7.7 & c \\
\hline $\mathrm{DIH} 5 \times 20^{\circ} \mathrm{C}$ & 3.43 & de & 0.32 & $d$ & 0.12 & $a b$ & 3.6 & $\mathrm{~h}$ \\
\hline $\mathrm{DIH} 5 \times 14^{\circ} \mathrm{C}$ & 3.01 & ef & 0.28 & ef & 0.12 & $a b$ & 3.9 & g \\
\hline $\mathrm{DIH} 5 \times 8^{\circ} \mathrm{C}$ & 2.40 & $g$ & 0.23 & $g$ & 0.12 & $a b$ & 4.0 & $g$ \\
\hline $\mathrm{DIH} 7 \times$ Control $(\mathrm{H})$ & 3.28 & de & 0.33 & $d$ & 0.09 & $\mathrm{bc}$ & 7.3 & $d$ \\
\hline $\mathrm{DIH} 7 \times 20^{\circ} \mathrm{C}$ & 3.52 & $d$ & 0.32 & $d$ & 0.12 & $a b$ & 1.2 & i \\
\hline $\mathrm{DIH} 7 \times 14^{\circ} \mathrm{C}$ & 3.11 & e & 0.28 & ef & 0.12 & $a b$ & 1.6 & $\mathrm{i}$ \\
\hline $\mathrm{DIH} 7 \times 8^{\circ} \mathrm{C}$ & 2.51 & g & 0.23 & $g$ & 0.12 & $a b$ & 1.9 & i \\
\hline
\end{tabular}

Data within a column followed by the same letter are not significantly different at $p \leq 0.05$ according to Duncan's test.

DIH 0 plantlets showed the best visual quality was detected in DIH 0 plantlets which in turn exhibited a significantly better visual quality than plants from DIH 1 and DIH 3 SSC. The lowest visual quality was observed in the plants subjected to the DIH 7 SSC. Regardless of the days in healing, the highest values were observed in control $(\mathrm{H})$ plantlets followed by those subjected to the 14 and $8^{\circ} \mathrm{C}$ SSC. ANOVA displayed a significant effect of the interaction DIH $\times$ SSC; the best results in terms of plantlet visual quality were obtained by DIH 0 plantlets, while the lowest scores were given from the combinations DIH $7 \times 20^{\circ} \mathrm{C}$, DIH $7 \times 14^{\circ} \mathrm{C}$, and DIH $7 \times 8^{\circ} \mathrm{C}$ (Table 4).

\section{Discussion}

The production/shipping method applied in this experiment has proved a valuable propagation/transportation technique for grafted eggplant plantlets. Grafting success was $100 \%$ and all un-rooted grafted cuttings developed roots at the end of the rooting stage. Our results also showed that grafted cuttings were not negatively affected by a shortterm exposure (72 hours) of simulated shipping conditions $\left(20,14\right.$, or $\left.8^{\circ} \mathrm{C}\right)$. These findings are different from those of Shibuya et al. (2008), who found that eggplant grafted cuttings are improved by warming of the graft union at the beginning of storage, but are in accord with those of the same authors concerning the positive effect due to higher temperatures on plant growth and development of the grafted plants.

During the rooting period, a few leaves from the un-rooted grafted cuttings became yellow and died off. Leaf yellowing and dying off were more evident when the grafted cuttings were treated at $20^{\circ} \mathrm{C}$ than at 14 or $8^{\circ} \mathrm{C}$. This is likely attributed to the higher respiratory loss of carbohydrate in eggplant cuttings as well as a potentially greater ethylene accumulation in cuttings during the 72-h simulated shipping temperatures at the higher temperature of $20^{\circ} \mathrm{C}$. Serek et al. (1998) demonstrated that in Dendranthema grandiflorum (Ramat.)
Kitamura, Pelargonium zonale L. and Hibiscus rosa-sinensis L. rapid senescence of mature leaves and impairment in subsequent root formation frequently occur as a result of extremes in post-harvest shipping environment. Rapaka et al. (2008), investigating the ethylene effect in postharvest leaf senescence of pelargonium cuttings, confirmed that ethylene sensitivity increased with decreasing pre-harvest endogenous carbohydrate status of the cuttings. The level of senescence of the scion leaves seemed to be pronounced when the grafted cuttings were subjected to the simulated shipping treatments, whereas, no leaf was affected by senescence in the non-treated control. However, plantlet length was higher when grafted cuttings were harvested after 3 days or more in healing. Thus, from one hand improving shipping conditions may successfully prevent leaf senescence, from the other hand a longer plantlet manipulation period (healing, shipping and rooting) as reported in Table 1, characterized by low light intensity, induced plant elongation. Adventitious rooting of un-rooted grafted cuttings depends on several factors such as genetic suitability for propagation. The results are in accord with those obtained by Miceli et al. (2014), who investigated eggplant suitability propagation by un-rooted grafted cutting using $S$. torvum. In the present experiment a shoot DW reduction was detected in cuttings harvested after 1 or more days in healing. This tendency was probably associated with the environmental conditions during the healing period. Therefore, the air temperature and the light intensity could be further optimized in order to attain at least null or positive carbon balance to the plants. Under continuous lighting conditions, the minimum light intensity to maintain the null carbon balance is the light compensation point at the temperature used in the system. With regard to healing, Johnson and Miles (2011) demonstrated that chamber design may affect healing conditions and thereby grafting success. They also found that tomato and eggplant seedlings 
were less sensitive to humidity control compared to other species like watermelon.

Overall, in the experiment the 'simulated shipping conditions' had no significant influence on grafting success, whereas it affected after-transportation seedling development. The results also show that plants subjected to the treatment DIH 0 [characterized by the shortest manipulation period (13 days from grafting to rooting)], gave the best results in terms of average leaf area and plantlet visual quality. Furthermore, simulation shipping temperature from 14 to $8^{\circ} \mathrm{C}$ permitted to maintain the best plantlet visual quality. Our findings are in accord with those of Kubota and Kroggel (2006), who reported that 6 to $13^{\circ} \mathrm{C}$ was the best tomato plant transportation temperature for up to 4 days.

\section{Conclusions}

The results showed that $S$. torvum is a suitable rootstock for applying this innovative production/shipping method based on the un-rooted grafted cutting propagation technique. Rooting ability and grafting success were not negatively affected by healing duration or 'simulated shipping treatments'. Post-rooting growth and development of rooted grafted cuttings were negatively affected by long plantlet manipulation time (from grafting to rooting), corresponding in an overall lower value of dry weight of the finished plug transplants. Shipping of un-rooted grafted eggplants immediately after grafting and 14 to $8^{\circ} \mathrm{C} S \mathrm{SS}$ are recommended to avoid negative effects on post-transportation growth, development and plantlet visual quality. Regardless of the shipping simulated conditions, the treatment DIH 0 gave the best results in terms of growth, development rates and plantlet visual quality of the finished plug transplants. This innovative production/shipping method might be successfully used to improve plant nursery efficiency in areas where local nurseries do not have high grafting ability. Further studies are required to assess other factors associated with the quality of the grafted plants, such as materials and packing conditions, vibrations during transportation.

\section{References}

Bagnaresi, P., Sala, T., Irdani, T., Scotto, C., Lamontanara, A., Beretta, M., Rotino, G.L., Sestili, S., Cattivelli, L., and Sabatini, E. (2013). Solanum torvum responses to the root-knot nematode Meloidogyne incognita. BMC Genomics 14, 540. https://doi.org/10.1186/14712164-14-540

Bletsos, F., Thanassoulopoulos, C., and Roupakias, D. (2003). Effect of grafting on growth, yield and Verticillium wilt of eggplant. HortScience 38, 183-186. https://doi.org/10.21273/HORTSCI.38.2.183.

Colla, G., Suãrez, C.M.C., Cardarelli, M., and Rouphael, Y. (2010a). Improving nitrogen use efficiency in melon by grafting. HortScience 45, 559-565. https://doi.org/10.21273/HORTSCI.45.4.559.

Colla, G., Rouphael, Y., Cardarelli, M., Salerno, A., and Rea, E. (2010b). The effectiveness of grafting to improve alkalinity tolerance in watermelon. Environ. Exp. Bot. 68, 283-291. https://doi. org/10.1016/j.envexpbot.2009.12.005

Dong, H.H., Niu, Y.H., Li, W.J., and Zhang, D.M. (2008). Effects of cotton rootstock on endogenous cytokinins and abscisic acid in xylem sap and leaves in relation to leaf senescence. J. Exp. Bot. 59, 1295-1304. https://doi.org/10.1093/jxb/ern035.

Gisbert, C., Prohens, J., Raigón, M.D., Stommel, J.R., and Nuez, F. (2011). Eggplant relatives as sources of variation for developing new rootstocks: Effects of grafting on eggplant yield and fruit apparent quality and composition. Sci. Hortic. 128, 14-22. https:// doi.org/10.1016/j.scienta.2010.12.007.
He, Y., Zhua, Z., Yang, J., Ni, X., and Zhu, B. (2009). Grafting increases the salt tolerance of tomato by improvement of photosynthesis and enhancement of antioxidant enzymes activity. Environ. Exp. Bot. 66, 270-278. https://doi.org/10.1016/j.envexpbot.2009.02.007.

Johnson, S.J., and Miles, C.A. (2011). Effect of healing chamber design on the survival of grafted eggplant, tomato and watermelon. HortTechnology 21, 752-758. https://doi.org/10.21273/ HORTTECH.21.6.752.

King, S.R., Davis, A.R., Zhang, X., and Crosby, K. (2010). Genetics, breeding and selection of rootstocks for Solanaceae and Cucurbitaceae. Sci. Hortic. 127, 106-111. https://doi.org/10.1016/j. scienta.2010.08.001.

Kubota, C., and Kroggel, M. (2006). Air temperature and illumination during transportation affect quality of mature tomato seedlings. HortScience 41, 1640-1644. https://doi.org/10.21273/ HORTSCI.41.7.1640.

Lee, J.M., Kubota, C., Tsao, S.J., Bie, Z., Hoyos Echevarria, P., Morra, L., and Oda, M. (2010). Current status of vegetable grafting: diffusion, grafting techniques, automation. Sci. Hortic. 127, 93-105. https:// doi.org/10.1016/j.scienta.2010.08.003.

Martinez-Rodriguez, M.M., Estan, M.T., Moyano, E., Garcia-Abellan, J.O., Flores, F.B., Campos, J.F., Al-Azzawi, M.J., Flowers, T.J., and Bolarín, M.C. (2008). The effectiveness of grafting to improve salt tolerance in tomato when an 'excluder' genotype is used as scion. Environ. Exp. Bot. 63, 392-401. https://doi.org/10.1016/j. envexpbot.2007.12.007.

Miceli, A., Sabatino, L., Moncada, A., Vetrano, F., and D’Anna, F. (2014). Nursery and field evaluation of eggplant grafted onto un-rooted cuttings of Solanum torvum Sw. Sci. Hortic. 178, 203-210. https:// doi.org/10.1016/j.scienta.2014.08.025.

Otani, T., and Seike, N. (2006). Comparative effects of rootstock and scion on dieldrin and endrin uptake by grafted cucumber (Cucumis sativus). J. Pestic. Sci. 31, 316-321. https://doi.org/10.1584/ jpestics.31.316.

Otani, T., and Seike, N. (2007). Rootstock control of fruit dieldrin concentration in grafted cucumber (Cucumis sativus). J. Pestic. Sci. 32, 235-242. https://doi.org/10.1584/jpestics.G06-49.

Rapaka, V.K., Faust, J.E., Dole, J.M., and Runkle, E.S. (2008). Endogenous carbohydrate status affects postharvest ethylene sensitivity in relation to leaf senescence and adventitious root formation in Pelargonium cuttings. Postharvest Biol. and Technol. 48(2), 272282. https://doi.org/10.1016/j.postharvbio.2007.10.001.

Rivero, R.M., Ruiz, J.M., Sanchez, E., and Romero, L. (2003). Does grafting provide tomato plants an advantage against $\mathrm{H}_{2} \mathrm{O}_{2}$ production under conditions of thermal shock? Physiol. Plant. 117, 44-50. https://doi.org/10.1034/j.1399-3054.2003.1170105.x.

Rouphael, Y., Cardarelli, M., and Colla, G. (2008). Grafting of cucumber as a means to minimize copper toxicity. Environ. Exp. Bot. 63, 49-58. https://doi.org/10.1016/j.envexpbot.2007.10.015.

Sabatino, L., Palazzolo, E., and D’Anna, F. (2013). Grafting suitability of Sicilian eggplant ecotypes onto Solanum torvum: Fruit composition, production and phenology. J. Food Agric. Environm. 11(3\&4), 11951200 .

Sabatino, L., Iapichino, G., Maggio, A., D’Anna, E., Bruno, M., and D'Anna, F. (2016). Grafting affects yield and phenolic profile of Solanum melongena L. landraces. J. Integr. Agric. 15(5), 1017-1024. https://doi.org/10.1016/S2095-3119(15)61323-5.

Sabatino, L., Iapichino, G., D’Anna, F., Palazzolo, E., Mennella, G., and Rotino, G.L. (2018). Hybrids and allied species as potential rootstocks for eggplant: Effect of grafting on vigour, yield and overall fruit quality traits. Sci. Hortic. 228, 81-90. https://doi.org/10.1016/j. scienta.2017.10.020. 
Savvas, D., Papastavrou, D., Ntatsi, G., Ropokis, A., Olympios, C., Hartmann, H., and Schwarz, D. (2009). Interactive effects of grafting and Mn-supply level on growth, yield and nutrient uptake by tomato. HortScience 44, 1978-1982. https://doi.org/10.21273/ HORTSCI.44.7.1978.

Serek, M., Prabucki, A., Sisler, E.C., and Andersen, A.S. (1998). Inhibitors of ethylene action affect final quality and rooting of cuttings before and after storage. HortScience 33(1), 153-155.

Shibuya, T., Tokuda, A., Terakura, R., Shimizu-Maruo, K., Sugiwaki, H., Kitaya, Y., and Kiyota, M. (2007). Short-term bottom-heat treatment during low-air-temperature storage improves rooting in squash (Cucurbita moschata Duch.) cuttings used for rootstock of cucumber (Cucumis sativus L.). J. Japan. Soc. Hortic. Sci. 76(2), 139-143. https:// doi.org/10.2503/jjshs.76.139.

Shibuya, T., Nakashima, H., Shimizu-Maruo, K., and Kawara, T. (2008). Improvement of storage quality of eggplant grafted cuttings by warming of graft union at the beginning of low-air-temperature storage. Europ. J. Hortic. Sci. 73(5), 196-200.

Shiraki, M., Kushima, H., Koiwasaki, K., Noma, H., Iwashita, T., and Eto, T. (1999). The distribution of tomato (Lycopersicon esculentum) and cucumber (Cucumis sativus) cutting grafting before rooted nursery plant. Bulletin of the Miyazaki Agricultural Experiment Station (Japan).

Venema, J.H., Dijk, B.E., Bax, J.M., Van Hasselt, P.R., and Elzenga, J.T.M. (2008). Grafting tomato (Solanum lycopersicum) onto the rootstock of a high-altitude accession of Solanum habrochaites improves suboptimal-temperature tolerance. Environ. Exp. Bot. 63, 359-367. https://doi.org/10.1016/j.envexpbot.2007.12.015.

Received: Jul. 23, 2018

Accepted: Feb. 13, 2019

Address of authors:

L. Sabatino*, F. D’Anna and G. Iapichino

Department of Agricultural, Alimentary and Forest Sciences,

University of Palermo, Palermo 90128, Italy

* Corresponding author; E-mail: leo.sabatino@unipa.it

Tel.: 0039329 8016975; Fax: 003909162240 